\title{
LA TEOLOGÍA POLÍTICA DE LA SECULARIZACIÓN. PEDRO DE BASALDÚA Y EL EXILIO VASCO EN ARGENTINA
}

\author{
THE POLITICAL THEOLOGY OF SECULARIZATION. \\ PEDRO DE BASALDÚA AND THE BASQUE EXILE IN ARGENTINA
}

José Zanca*

Consejo Nacional de Investigaciones Científicas y Técnicas (CONICET)/ Universidad de San Andrés, Buenos Aires, Argentina

\begin{abstract}
RESUMEN: Desde el inicio de la Guerra Civil española, las diferencias entre los católicos argentinos se tradujeron en el apoyo a disímiles modelos políticos que traslucían, a su vez, querellas teológicas. Los nacionalistas vascos, católicos y aliados a la República, pusieron a los intelectuales confesionales sudamericanos frente a una compleja situación. La alianza entre Franco y Perón - ambos apoyados por la Iglesia Católica - impulsó una reflexión teológica sobre lo político en el sentido de un proyecto demócrata cristiano. El presente artículo propone dar cuenta de esta transformación, analizando la circulación de ideas entre los exiliados vascos y los católicos argentinos, concentrándose en la figura de Pedro de Basaldúa, un destacado político, intelectual y articulador étnico-cultural en la segunda mitad del siglo Xx entre Europa y América Latina.
\end{abstract}

PALABRAS CLAVE: Humanismo cristiano - Nacionalismo vasco - Teología política - intelectuales católicos

\begin{abstract}
Since the beginning of the Spanish Civil War, Argentine Catholics defended different political models, based on various theological principles. The case of Basque nationalism, fervently Catholic and allied with the Republic, created a dilemma for the confessional South American intellectuals. The alliance between Franco and Perón - both supported by the Catholic Churchprompted a theological reflection on the political in the sense of a Christian Democratic project. This article attempts to account for this transformation, analyzing the circulation of ideas between Basque exiles and Argentine Catholics, concentrating on the figure of Pedro de Basaldúa, a prominent political, intellectual and ethnic-cultural articulator in the second half of the twentieth century between Europe and Latin America.
\end{abstract}

KEYWORDS: Christian Humanism - Basque Nationalism - Political Theology-Catholic Intellectuals

* Correspondencia a: José Zanca. Universidad de San Andrés, Departamento de Humanidades, Vito Dumas 284, B1644BID Victoria, Buenos Aires, Argentina - jzanca@udesa.edu.ar - https://orcid.org/0000-0002-0552-4618

Cómo citar: Zanca, José (2020). "La teología política de la secularización. Pedro de Basaldúa y el exilio vasco en Argentina»; Historia Contemporánea, 63, 547-581. (https://doi.org/10.1387/hc.20963).

Recibido: 27 junio, 2019; aceptado: 30 septiembre, 2019.

ISSN 1130-2402 - eISSN 2340-0277 / (C) 2020 UPV/EHU 
Un cristiano no se sabe bendito hasta que no sabe que otro no lo es.

Joyce Carol Oates

\section{Introducción}

Desde el inicio de la Guerra Civil y durante la Segunda Guerra mundial el régimen franquista puso en marcha una política cultural destinada a difundir el concepto de hispanidad entre los países de América Latina. No había sido el primero en politizar el término, pero lo utilizó para recuperar un papel hegemónico en la región y ganar apoyos apelando a un sentimiento de comunidad. El Congreso de Pax Romana de 1946 y el lanzamiento del Instituto de Cultura Hispánica (continuador del falangista Consejo de la Hispanidad) fueron algunos hitos de esa política que coincidió con el ascenso de Juan Domingo Perón en Argentina y la construcción de una alianza con Franco. Si bien el arribo al poder del peronismo se produjo a través de elecciones libres, venía precedido por más de una década de cuestionamientos a la democracia liberal. Los intelectuales católicos habían sido protagonistas de esta reacción antimoderna, y desde el inicio de la Guerra Civil española se habían confrontado en el campo religioso diferentes modelos políticos, sustentados en diversos principios teológicamente justificados. El caso del nacionalismo vasco, católico y aliado a la República, puso a los intelectuales católicos argentinos frente a una compleja situación ¿El régimen instaurado en España representaba acaso el ideal de cristiandad al que aspiraban? ¿Qué datos aportaba sobre las formas autoritarias de gobierno y sus vínculos con la teología política? ${ }^{1}$ A comienzos de

${ }^{1}$ El término teología política tiene una extensa historia dentro del pensamiento jurídico y filosófico. Carl Schmitt, si bien no inventó el término, le dio un horizonte semántico que se extendería durante buena parte del siglo xx. Dos de sus obras, Teología política, de 1922, y Catolicismo y forma política, de 1923, marcaron los principios de su interpretación de las relaciones entre la cultura política europea y la revelación cristiana. En el primero de esos trabajos sostenía que «Todos los conceptos centrales de la moderna teoría del Estado son conceptos teológicos secularizados» (Schmitt, 2009 (1922), p. 37). En el segundo afirmaba que la autoridad no podía escindirse de la teología y de la moral (Schmitt, 2001 (1923)). En los años sesenta, con los efectos del Concilio Vaticano II en el campo de las ideas católicas, se abrió la posibilidad de elaborar una teología política centrada en los dominados, y menos en las formas legítimas de dominación. Surgió así una teología política de tipo mesiánica, basada en el Hijo más que en el Padre, de carácter revolucionario y 
la Guerra Civil la mayor parte de los católicos apoyaron el bando rebelde. Pero a medida que pasaron los meses, el caso vasco llenó de dudas a muchos de sus militantes. ¿Por qué los vascos no se afiliaban a un gobierno que parecía dispuesto a instaurar los principios políticos que el catolicismo había defendido desde el siglo XIX? ¿Por qué, por el contrario, adhirieron al - todavía no muy claramente definido- «humanismo cristiano»?

Las polémicas en torno al fascismo y el nacionalismo de derecha muestra que las fricciones internas sacaban a la superficie la heterogeneidad del catolicismo y sus diferencias teológicas. En Sudamérica se concentró un segmento importante de sacerdotes y laicos hispanófilos que vieron en la cruzada franquista una posible vía para enfrentar a la modernidad y restaurar la cristiandad. En oposición, frente al espejo del modelo español -que no era sólo un prototipo político autoritario, sino también un modelo de interacción entre la iglesia, la sociedad y el Estado - católicos antifascistas elaboraron un conjunto de juicios que conformarían un nuevo corpus teológico. ${ }^{2}$ La circulación de ideas entre el viejo y nuevo continente puede ser un interesante vehículo para comprender las nue-

cuyo efecto puede detectarse en América Latina a través de la Teología de la Liberación. La figura del teólogo alemán Johann Baptist Metz fue central en ese caso. Más allá de estas diferencias, el principio de continuidad entre lo religioso y lo secular pone en cuestión la separación de esferas y su legitimidad inmanente, propia del pensamiento liberal. Por ello el concepto fue cuestionado por hacer depender a la política de una fuente externa. Así lo recuerda Galindo Hervás al sostener que las diversas formas que adquiere la teología política «[...]....apuntan a un cuestionamiento radical de los dos pilares que definen genéricamente la política moderna: por un lado, la posibilidad de representar el orden, de traducir jurídicamente y así visualizar la voluntad general; por otro, la fe en la acción y en su potencial emancipador» (Hervás, 2011, p. 181). A los efectos de este trabajo, que analiza las apropiaciones y usos de la teología por parte de militantes nacionalistas, utilizamos el concepto de teología política como una narrativa que asegura estar basada en la fe de la revelación divina. Una forma de entender la dominación legítima, y al mismo tiempo, de cuestionar las acciones que son consideradas ilegítimas a la luz de esos mismos principios evangélicos. El concepto de teología política tiene, en ese sentido, dos vías por las que se relaciona con la secularización. En el sentido que le daba Schmitt, se trata de una traducción de conceptos de una esfera a la otra; en términos de una sociología de la religión, se trata de la disminución de la potestad de los consagrados (jerarquía y clero) en favor de otros intérpretes - en su mayoría laicos - que desafían, implícitamente, el monopolio de la autoridad. Sobre el concepto de teología política véase Monod, 2002; Meier, 2006; Meier, 2009; Nosetto, 2014.

${ }^{2}$ El presente artículo no vuelve sobre los detalles de la polémica entre los católicos a propósito de la Guerra civil y del caso vasco, que han sido tratados en otros trabajos. Véase Zanca, 2009 y Zanca, 2014-2015. 
vas definiciones de lo laico y lo religioso que se debatían durante los años de 1940.

\section{Adiós a la secularización}

Las relaciones entre religión y política ocupan, desde hace tiempo, un lugar destacado en la agenda de las ciencias sociales. Con picos de interés y valles de apatía, la pregunta por una dinámica que se creía resuelta desde fines del siglo XIX a través del paradigma de la secularización se ha vuelto problemática al menos desde fines de la década de 1970. El secularismo - es decir, la confluencia entre la teoría de la secularización y la prescripción de la secularidad - se convirtió en un paradigma naturalizado entre sociólogos, cientistas políticos e historiadores. Desde esa perspectiva, partidos políticos y organizaciones de la sociedad civil eran juzgados en tanto colaboraran - o no- en la constitución de una esfera política democrática e igualitaria, es decir, ajena a todo rasgo religioso.

En los últimos años, los estudios sobre las relaciones entre política y religión - de la mano de los debates en torno al concepto de secularización - han mudado muchas de estas perspectivas. La deconstrucción del concepto abrió nuevas posibilidades para analizar las diversas formas en las que lo religioso y lo político se encuentran y relacionan. A los efectos de este trabajo, adoptaremos la perspectiva que define a la secularización como una narrativa a través de la cual los modernos constituyeron sus impresiones sobre el fenómeno religioso. La idea de una trama textual no excluye la perspectiva sociológica. Sin duda, la secularización sigue siendo un problema de poder. Resulta relevante entonces el análisis de la narración y la praxis discursiva sobre quién tiene el poder de definir los bienes de salvación y los medios para su acceso legítimo. ${ }^{3}$

El nacionalismo vasco, desde su origen, entrelazó su discurso con la teología cristiana. Definió los contornos de un «pueblo», constituido por una esencia que se trasladaría a lo largo del tiempo con pocos cambios. La historiografía ha señalado el carácter imaginario de esta construcción y su uso por parte de distintos segmentos de la sociedad vasca como mecanismo de autopreservación. ${ }^{4}$ El vínculo entre nacionalismo y reli-

\footnotetext{
3 Brown, 2006; Gentile, 2006; Bellah y Hammond, 2013.

${ }^{4}$ Louzao Villar y Molina Aparicio, 2014; Montero García, Cueva Merino y Louzao Villar, 2017; Botti, 2007.
} 
gión fue un componente central de esta narración. ${ }^{5}$ Ser vasco y ser católico se convirtieron en sinónimos para el relato del nacionalismo. No se trataba de dos términos equivalentes, dado que para Sabino Arana y sus seguidores la independencia se subordinaba a la religión. Como sostiene Louzao Villar, aparecía una teología política definida como nacionalcatolicismo, que confesionalizaba la nación, eliminando sus contenidos liberales. Era una cultura política basada en una teología de reconquista, organicista y corporativa de la sociedad organizada mediante cuerpos intermedios. Los primeros ideólogos del PNV lo remarcaban constantemente al articular el patriotismo con la fe. Más allá de que convivieran posiciones radicalizadas y moderadas, la independencia era un grito que se ligaba a la nación católica. ${ }^{6}$ Este nivel de interacción entre nacionalismo y religión ha permitido hablar de un nacionalismo religioso. La cultura vasca y el catolicismo estaban fusionados al punto que el nacionalismo era una llave para acceder a los bienes de salvación que proveía una religión trascendente. ${ }^{7}$

La concepción integralista del PNV pone en duda el supuesto carácter pluralista de la sociedad vasca de entreguerras. ${ }^{8}$ Sin embargo, aquí la teoría de la secularización muestra sus límites. En esta mirada lo descriptivo y lo prescriptivo parecen superponerse, dado que, a pesar de su supuesta expulsión de la esfera pública - propio de lo que debería ser una sociedad moderna y laica - lo religioso siguió funcionando como un mecanismo de simbolización de lo político. Se vuelve imperativo entonces tomar distancia de una narrativa ilustrada, deconstruyendo la representación de la esfera pública, un espacio imaginado - como señala el antropólogo Manuel Delgado-, desde fines del siglo XIX como «aula y laboratorio», en donde se ensayaría una ideología de la neutralidad para enmascarar la subsistencia de relaciones sociales conflictivas. ${ }^{9}$ Lejos de la desaparición de lo religioso, lo persistente es la adaptación de lo religioso a nuevos contextos

5 Puhle, 1982.

${ }^{6}$ Louzao Villar, 2015, p. 94. Sobre la historia del PNV a partir de la Guerra Civil, véase Meer, 1992; Jiménez de Aberasturi Corta, 1999; Pablo y Mees, 2005.

7 Martínez Rueda, 2018.

${ }^{8}$ Louzao Villar sostiene que la vasca fue una sociedad plural, pero fragmentada e intolerante. Ese mundo de los años veinte y treinta estuvo lejos de «...la promoción de la autonomía de los individuos, no su subordinación a fidelidad colectiva alguna, especialmente cuando ésta se sustenta en patrones de sacralización política». Louzao Villar y Molina Aparicio, 2014. Véase también Louzao Villar, 2011, en especial pp. 31-68.

9 Delgado, 2015. 
de modernidad. Así se observa en la supervivencia e hibridación de lo que creeríamos que debía estar separado.

\section{El exilio vasco en Argentina: singularidades e importancia}

Desde 1938 funcionaba en Buenos Aires una delegación del gobierno vasco formado en octubre de 1936. Originalmente la delegación tenía jurisdicción sudamericana, producto de la importancia de la estructura comunitaria en Argentina. Desde principios del siglo XX se había alimentado de sacerdotes abertzales, refractarios al modus vivendi que construyó la iglesia católica y el régimen de la Restauración. ${ }^{10}$ Se formó una sólida organización en términos numéricos, institucionales, dada la cantidad de asociaciones y centros culturales vascos. Existían desde fines del siglo XIX centros regionalistas, como Centro Laurak Bat, o el centro educativo Euskal Echea de Lavallol, multitud de centros vasquistas diseminados por la provincia de Buenos Aires, Córdoba y Santa Fe, así como en el resto del país. Desde los albores del nuevo siglo la comunidad vasca mostró signos de politización, con un alto nivel de información y compromiso con la situación europea, sobre la que se informaba a través de periódicos como La Baskonia, Irrintzi, Aitor, Danak Bat, Euzkotarra. El aporte de los sacerdotes abertazales fue muy importante, tanto por su papel como organizadores de centros vinculados al nacionalismo, como en su rol de polemistas con otros actores de la política española en Argentina. A lo largo de su historia, la delegación vasca en Argentina tuvo tres representantes: Ramón María Aldasoro Galarza (1938-1946) con José María Lasarte como secretario; Francisco de Basterretxea (1946-1951) ocupando en ese caso Pedro de Basaldúa Ibarmia la secretaría y finalmente el mismo Basaldúa (1951-1982), acompañado por Andoni de Astigarraga. ${ }^{11}$

Más allá de los militantes nacionalistas, ser vasco en Argentina tenía connotaciones singulares. Se lo asociaba al tesón, la laboriosidad y la piedad religiosa. En el imaginario colectivo lo vasco gozaba de legitimidad cultural y política, y sobre esas redes de reconocimiento e influencia se desplegaron los enviados del primer gobierno autonómico luego

10 En éste, como en muchos otros aspectos vinculados a la inmigración vasca y su inserción en distintos ámbitos en Argentina, remitimos a la obra de Oscar Álvarez Gila. Véase Álvarez Gila, 1994; Álvarez Gila, 1998a; Álvarez Gila, 1998b, Álvarez Gila,1999.

11 Koldo San Sebastián, 1988; Sanz Goikoetxea y Álvarez Gila, 2010. 
de la caída de Barcelona. En agosto de 1939 se constituyó el «Comité Pro inmigración vasca», integrado por destacadas figuras de la elite económica con ascendencia vasca, que se reunían en la Sociedad Rural Argentina. En enero de 1940 lograron que el presidente Ortiz aprobara un decreto distinguiendo y fomentando la inmigración de los vascos a la $\mathrm{Ar}$ gentina. Una excepción, dado que en julio de 1939 la inmigración europea había sido restringida frente al temor de una avalancha de refugiados «indeseables». ${ }^{12}$ En los considerandos del decreto se apelaba al imaginario sobre la condición vasca:

Que los propósitos que persigue el Comité Pro Inmigración Vasca son los de mantener y acrecentar esa corriente de inmigración que desde la constitución del país ha representado un vigoroso aporte a la población y al progreso de la Nación, por las cualidades de laboriosidad y de adaptación a nuestro medio económico social. ${ }^{13}$

Poco después llegaría al país Pedro de Basaldúa y se convertiría en una figura clave en el proceso de circulación de ideas, elaboración de vínculos, y construcción de redes comunitarias y políticas. Nacido en Barakaldo el 15 de abril de 1906, Basaldúa fue militante del nacionalismo vasco desde su juventud, y desde principios de los años treinta una figura cada vez más destacada en distintas instancias periodísticas y políticas. Encarcelado en varias ocasiones, en 1936 fue designado para representar al PNV en el Gobierno Civil de Bizkaia y sucesivamente fue secretario del gobierno civil y secretario particular del presidente José Antonio Aguirre. Al finalizar la Guerra Civil hizo el tortuoso recorrido de tantos expatriados, y recaló en playas argentinas en 1942 en un exilio que se extendió hasta su muerte, en $1985 . .^{14}$

Basaldúa funcionó como un nexo entre los distintos grupos demócrata cristianos sudamericanos. En sus viajes se contactaba con la Falange chilena, grupo demócrata cristiano liderado por Eduardo Frei y con el senador del Unión Cívica de Uruguay, Dardo Regules. En Argentina su apoyatura era Manuel Ordóñez y el grupo de notables reunidos en la revista Orden Cristiano desde fines de 1941: Rafael Pividal (fallecido en 1945), Augusto Durelli (en el exilio desde 1946), Manuel

12 Klich y Rapoport, 1997.

13 Decreto 53448 del 20 de enero de 1940. Aguirre, 2003.

14 Basaldúa, 1945. 
Río, Eugenia Silveyra de Oyuela, Angélica Fuselli, entre otros. Fuera de ese grupo tenía estrechas relaciones con el obispo de Temnos, Miguel de Andrea. El «obispo social» permitía que en sus actos la delegación vasca apareciera diferenciada de la española. Además de los sectores católicos, buena parte de la «Argentina liberal» figuraba entre las relaciones frecuentes del delegado: directores de diarios, periodistas, dirigentes de partidos de izquierda de acendrado anticlericalismo, unidos por el antifascismo que en Argentina se extendió en el tiempo gracias a la presencia del peronismo. Algunos de sus contactos frecuentes en Buenos Aires eran el socialista Américo Ghioldi, el católico liberal Octavio Amadeo, el diplomático José Maria Cantilo, Alberto Gainza Paz, dueño del liberal diario La Prensa, Juan Valmaggia, periodista del diario La Nación, y el reformista y académico Horacio Rivarola.

Basaldúa abogó por una «democracia cristiana» que, según su perspectiva, era más que una opción política: se trataba de un modelo alternativo de cristianismo. Sin embargo, no parecía encontrar más que hostilidad entre las elites católicas sudamericanas, tanto en la jerarquía como entre los laicos. La «hispanidad», en oposición al panamericanismo propagado por los norteamericanos, tenía más éxito entre los católicos de este lado del continente. En Argentina, los demócratas cristianos y la jerarquía de la iglesia católica sostuvieron relaciones hostiles. Los primeros adoptaron una postura antifascista durante la Segunda Guerra mundial, y se aliaron a radicales, socialistas e incluso comunistas en muchas agrupaciones cívico-políticas, como Acción Argentina, en donde Rafael Pividal formó parte de su Comité Ejecutivo, o la Junta de la Victoria, en la cual Eugenia Silveyra de Oyuela tenía una destacada participación. ${ }^{15}$ La cúpula eclesiástica prefería seguir la política de neutralidad vaticana. A eso se sumaba que el gobierno militar surgido del golpe de estado del 4 de junio de 1943 había integrado en sus elencos a los grupos nacionalistas - y en su mayoría, pro-Eje - del catolicismo, y era acusado públicamente de utilizar la neutralidad como un mecanismo para favorecer la suerte de Alemania. ${ }^{16}$ En esta red de complejas tensiones debían actuar los nacionalistas vascos. Por un lado, en el plano religioso, dando batalla contra los nacionalistas, pero sin romper relaciones con sus padrinos, los jerarcas de la iglesia católica argentina. En el plano político, insertos

15 Andrés Bisso, 2005; McGee Deutsch, 2013.

16 Halperín Donghi, 2004. 
- como en España - en el bloque antifascista. Un conjunto heterogéneo en el que eran constantes los recelos y sospechas mutuas.

Si bien la idea de una democracia cristiana no era nueva, estaba adquiriendo un nuevo contenido en los años cuarenta. En América como en Europa significaban el ingreso de un segmento de militancia mixta (étnica política, religiosa, social o estrictamente política) por un canal de participación que conjugaba principios socialcristianos y un fuerte deseo de mantenerse autónomos del diktat de la jerarquía católica. Los nacionalistas vascos debían confrontar el hispanismo de los nacionalistas católicos argentinos, que habían ganado espacio en la Argentina de los años treinta. Una agresiva política cultural de España hacia América Latina se había iniciado en el siglo XIX, y cobró fuerza a partir de $1910 .{ }^{17} \mathrm{El}$ concepto de hispanidad tuvo difusión en los círculos intelectuales argentinos en los años de 1920 de la mano de Ramiro de Maetzu, embajador de la dictadura de Primo de Rivera entre 1928 y 1930. La revista católica Criterio incorporó como asesor a otro de sus adalides, el sacerdote de origen vasco Zacarías de Vizcarra. ${ }^{18}$ Ambos reactualizaron y le dieron un nuevo sentido político al concepto de hispanidad, como un adjetivo que podía oponerse a otras definiciones identitarias de la primera posguerra. El estallido de la Guerra Civil colocó a España en un lugar privilegiado del imaginario de los grupos católico-nacionalistas. En la Península Ibérica se volcaban muchas de las expectativas de un cambio radical en el curso de la historia europea y americana en el que geopolítica y religión se superponían. España era la silueta imaginaria de una nación pura, que rechazaba los males de la modernidad - burguesismo, comunismo, laicismo, liberalismo, judaísmo - y se ponía a la cabeza de un gran proyecto universal: la restauración de la cristiandad. ${ }^{19}$

Al principio de la Guerra Civil española, Buenos Aires fue el escenario del enfrentamiento entre católicos franquistas y antifranquistas. Con la visita de Jacques Maritain a la capital argentina a propósito del Congreso del PEN Club de 1936, la situación española fue la piedra de toque que enfrentó, en los principales medios católicos, a nacionalistas y humanistas cristianos. Fue a partir de ese posicionamiento de Maritain que su filo-

17 Prado, 2008; López Sánchez, 2013.

18 Abellán y Monclús, 1989; González Cuevas, 2003; González Cuevas, 2005.

19 Sobre la hispanidad en Argentina, más allá de los trabajos sobre el nacionalismo de derecha, véase Iannini, 2013 y Iannini, 2015. Sobre la revista Criterio, véase Zanatta, 1996, Devoto, 2009, Lida y Fabris, 2019, Pattin, 2019. 
sofía política - cristalizada en su libro Humanismo integral - comenzó a ser cuestionada a nivel internacional. La Guerra Civil y el diseño de una nueva teología se encontraron en Sudamérica. ${ }^{20}$

Con el fin de la Guerra Civil la hispanidad adquirió ribetes imperialistas en el bando vencedor. Pero la derrota del Eje en la Segunda Guerra, y la llegada del peronismo al poder en Argentina, cambiaron el escenario. En 1945 el régimen de Franco estaba aislado y cosechaba opositores en Estados Unidos y Europa. En América Latina, los demócratas cristianos operaban contra el franquismo, según lo reflejaban los telegramas de sus diplomáticos. ${ }^{21}$ Franco cambio el rumbo e incorporó a los católicos al gobierno, otorgándole al régimen toda una red de «propagandistas», entre los que se destacaban obispos, sacerdotes y nuncios. ${ }^{22}$ Cerró el Consejo de la Hispanidad y privilegió a los militantes de la Acción Católica, en detrimento de los falangistas. El Vaticano era un firme apoyo para el gobierno español, a quién percibían como una barrera ante el comunismo, mucho antes de que los Estados Unidos viera la oportunidad que se le abría en la Península Ibérica. El congreso de Pax Romana en 1946 en Madrid permitió el encuentro de intelectuales católicos españoles y latinoamericanos que vibraban al unísono en los primeros minutos de la Guerra Fría. La delegación argentina fue una de las más numerosas, en la que se destacó el sacerdote Juan Sepich, una figura importante de los Cursos de Cultura Católica de Buenos Aires y con aceitados vínculos con los grupos nacionalistas de derecha. ${ }^{23}$ En su ponencia para la cuarta sesión afirmaba, entre otros lineamientos, que la función de los estados cristianos sería la de restaurar la autoridad, «devenida de Dios y que va hacia Dios». En esas circunstancias la hispanidad era para Sepich el punto donde se enlazaban y se organizaban los medios que habían de llevar «a la solución de los problemas internos y externos de las comunidades políticas», era «la concreción a que aspira un grupo de naciones que han recibido un patrimonio humano, histórico, cultural, geográfico y económico nacido de una raíz, de lo que fue gran Estado cristiano». ${ }^{24}$

20 Véase Compagnon, 2003; Zanca, 2014. Sobre los debates y las apropiaciones teológicas de la violencia y la guerra civil española, véase Zamagni, 2013; Zamagni, 2016.

21 Zanatta, 2008.

22 Tusell, 1984.

${ }^{23}$ Fares, 2016.

24 Sepich, 1946. 
En 1947 se fundó el Instituto de Cultura Hispánica, bajo la dirección de Joaquín Ruiz Giménez, quien en 1948 accedió al cargo de embajador ante la Santa Sede, traspasando el mando a Alfredo Sánchez Bella, una figura clave en la política y expansión de la obra del instituto. En términos ideológicos, tanto Sánchez Bella como Ruiz Giménez y Martín Artajo coincidían en la necesidad de difundir un modelo de catolicismo integral, donde la cultura ocupaba un papel central en la constitución de la soberanía política. Tanto la gestión de Ruiz Giménez como, a posteriori, la de Sánchez Bella al frente del Instituto se amoldaban al carisma de la Asociación Católica Nacional de Propagandistas (ACNdP), de la que formaban parte y, sobre todo, a las tesis de Ángel Herrera Oria respecto de la evangelización de la cultura como factor clave para la unidad social y política, en una suerte de tradicionalismo renovado que se proyectaba hacia fuera. ${ }^{25} \mathrm{El}$ instituto tuvo una activa política respecto de los argentinos, promoviendo viajes, homenajes y becas de estudio. Los obispos Antonio Caggiano (de Rosario) y Agustín Barrére (de Tucumán) viajaron a España y se convirtieron, a su regreso, en abogados del régimen franquista. En fin, el catolicismo franquista tenía claro que su imagen en la prensa internacional - en especial la católica - era fundamental para sacar a España del aislamiento. Por ello, el estado español gastaba ingentes recursos para mantener bien activa su propaganda en América Latina.

Desde 1946, la política de Juan Domingo Perón, su pacto con Franco y el apoyo a la hispanidad fue una forma de reafirmar su «tercera posición» respecto de los grandes bloques de la posguerra. ${ }^{26}$ Argentina se convirtió a partir de los acuerdos en una gran propagandista y embajadora de los intereses de España en los foros internacionales. Presionó a sus vecinos de América Latina a través de la diplomacia y del uso de recursos - créditos y materias primas - que podía utilizar gracias a su buen pasar económico. Este idilio se mantuvo hasta fines de los cuarenta, cuando España se vio beneficiada por el inicio de la Guerra Fría. El nuevo escenario beneficiaba a Franco, que hablaba ahora de Occidente, y se olvidaba de la Hispanidad. En revancha, Perón también abandonó la hispanidad para abrazarse a la idea de Latinidad. ${ }^{27}$

Vivir bajo el peronismo le permitió al exilio vasco observar en directo una forma de relación entre política y religión que, si bien no llegaba a los

25 Cañellas Mas, 2014.

26 Sobre el pacto Perón-Franco, véase Rein, 2003; Schwarzstein, 2001.

27 Zanatta, 2008. 
niveles de confluencia a los que arribaba en España, mostraban una asombrosa complementariedad, extraña en un país caracterizado - por los mismos exiliados vascos - por un acendrado laicismo. La red de notables en la que se insertó Basaldúa - la Argentina liberal - se indignaba por el comportamiento de la Iglesia Católica frente al estado justicialista. Los informes de la delegación en Buenos Aires están plagados de comentarios al respecto. En un extenso memorándum sobre la situación religiosa, afirmaba que:

La minoría nacionalista-totalitaria católica y el clero reaccionario dan el perfil actual de la iglesia; y como ello acontece en un momento crucial de la Patria, la posición es grávida de consecuencias incalculables. [...] Los acompaña y aprovecha, cuando no los dirige, una minoría intelectual de laicos, muchos de ellos de vida correcta en otros sentidos; pero de formación muy deficiente; están influidos por el milenarismo y el iluminismo (Guenon); son nacionalistas y antisemitas, partidarios de la violencia y unidos espiritualmente a la Falange de España, se han comprometido irrevocablemente con Perón y han arrastrado a ese compromiso a la Iglesia. ${ }^{28}$

En ese cuadro, el presidente Perón pretendía cumplir el rol de «gerente laico de la Iglesia». Todas sus dádivas fueron para justificar «su entrometimiento cada vez mayor en asuntos mixtos y puramente eclesiásticos». A partir de 1946 la actividad de Basaldúa estuvo resueltamente orientada a unir y coordinar a los grupos demócrata cristianos argentinos y sudamericanos. A principios de 1947 salió de gira por el continente para reclutar voluntades. En sus informes le explicaba a Aguirre la compleja situación política. «Terra Aroncena afirma que el mal que padece América es el de la influencia política que ejercen las Órdenes religiosas y el clero español», afirmaba, «que de modo legal o moral miran a España y de allí reciben instrucciones y normas. Los religiosos siguen atados al carro español [...] Durante la guerra franquista, ese fenómeno ha sido una de las causas más importantes para ganar la opinión católica». En Chile entrevistó con los hombres de la Falange, interesados en que fuera el nexo para un encuentro continental. Afirmaba que el candidato triunfante en las últimas elecciones, Gabriel González Videla, estaba apoyado por so-

28 «Memorándum acerca de la situación del catolicismo en Argentina» (1952), Fondo Manuel Irujo (Caja 52, Clave:2325, Signatura J). 
cialistas y comunistas, que tenían gran influencia en el gobierno y que se distinguían por su benevolencia con el peronismo. La Falange era para Basaldúa el partido ejemplar: «...han penetrado a fondo en las organizaciones universitarias y sindicales y es en definitiva un partido de porvenir». El cardenal chileno José María Caro Rodríguez se había mostrado hostil a los antifranquistas por las presiones que supuestamente ejercía el nuncio Maurilio Silvani: «Actualmente rodean al cardenal dos hombres franquistas»..$^{29}$ En Brasil tomó contacto con Alceu Amoroso Lima, un intelectual «... de enorme influencia en los medios católicos de Sudamérica. Antes de la Guerra Civil era una de las personalidades más importantes del catolicismo brasileño y el niño mimado del episcopado. Perdió esos afectos al declararse antifranquista.» ${ }^{30}$

En Argentina, el compromiso de la iglesia con el peronismo era absoluto. La jerarquía también se miraba en el espejo español. Según Basaldúa entre los obispos predominan los elementos autoritarios:

Recientemente Mons. Copello, arzobispo y cardenal, recriminó a un amigo mío, el doctor Manuel Río, ex profesor universitario, por la actitud que fijamos los católicos demócratas en relación a España ya que el desprestigio al régimen suponía un desprestigio a la Iglesia. No sólo España, dijo, sino también Argentina, precisa un Franco. Ese y no otro es el criterio del episcopado. ${ }^{31}$

Para Basaldúa el catolicismo argentino dependía del español. Sus obispos miraban «más a Toledo que a Roma», y buscaban asemejarse a la iglesia peninsular, en sus características más lamentables. «Ha perdido sobre todo el sentido universalista, se ha localizado, nacionalizado. De ahí que se vea con recelo inmenso la conducta y obra del Episcopado norteamericano y de los católicos norteamericanos, a quienes creen contaminados de las "esencias liberticidas protestantes"». ${ }^{32}$ A la sumisión de la jerarquía a España se sumaba la colaboración del estado franquista para subvencionar los viajes de destacadas figuras del nacionalismo argentino. El nacionalista Carlos Ibarguren explotaba su lugar de presidente de la Academia Argentina de Letras, Mario Amadeo y Juan Carlos Goyeneche

\footnotetext{
29 Carta a Aguirre. 3 de febrero de 1947. AN-GE-654-1.

30 Carta a Aguirre. 4 de agosto de 1947. AN-GE-654-1.

31 Carta a Aguirre. 2 de octubre de 1947. AN-GE-654-1.

32 Carta a Aguirre. 10 de diciembre de 1947. AN-GE-654-1.
} 
controlaban el flujo de argentinos a través del Instituto de Cultura Hispánica, y del Instituto Cultural Iberoamericano en Argentina. ${ }^{33}$

En 1947 los esfuerzos por unir a los dispersos y embrionarios grupos demócrata cristianos rindieron sus frutos. En una carta dirigida a José María de Lasarte, Basaldúa exponía un detallado racconto de la primera reunión de líderes demócrata cristianos sudamericanos llevada a cabo en Montevideo. Se había acordado la fundación de un movimiento supranacional, basado en los principios del humanismo cristiano, que no tendría carácter confesional e impugnaría todos los totalitarismos. Buscaría formar «una comunidad internacional de derecho», rechazando los nacionalismos, los imperialismos, los antisemitismos y todas las tendencias que provocaran la discordia y la guerra.

En síntesis, los vínculos entre estados autoritarios e iglesia terminaban mostrando la dependencia eclesiástica respecto del poder civil, donde lo espiritual ocupaba un papel subordinado. Era necesario entonces repensar esa relación a la luz de la experiencia de la Guerra Civil, la Guerra mundial y el exilio. De un lado y el otro del océano, con el franquismo y con el peronismo, los nacionalistas vascos elaboraron una crítica a la cristiandad. ¿Qué teología fundaría una forma diferente de intervención política de los laicos?

\section{Nueva teología política y nacionalismo vasco}

A lo largo de la década de 1930 y 1940 la experiencia del Guerra Civil, el exilio y la decepción por la supervivencia política de Franco en los años cincuenta delinearon una nueva teología política, construida en oposición al nacionalismo católico argentino que defendía a la España franquista y su modelo de estado confesional. Esa teología política implicaba una nueva antropología, traduciendo la noción de derechos individuales al lenguaje católico. Ya no era la iglesia el bien jurídico a tutelar, sino los hombres frente al estado autoritario. Resulta clave en este aspecto la imagen que devolvió la iglesia de Roma, y las iglesias locales - como es el caso del episcopado español- en sus relaciones con los regímenes políticos. La realpolitik practicada por el Vaticano, el maquiavelismo de la curia durante la crisis europea de entreguerras, estaba escandalosamente

${ }^{33}$ Carta a Aguirre. 20 de febrero de 1948. AN-GE-654-1. 
orientada por la conveniencia. En mayo de 1951 Manuel de Irujo en una carta al EBB del PNV, recordaba el impacto que le causó el poco interés por los «principios» que había demostrado el cardenal Verdier, por cierto, amigo de los vascos. «El cardenal Verdier, cuando en presencia de los Sres. Aguirre y Monzón, le hablaba yo de las dificultades que el Vaticano oponía a la normalización de la vida religiosa en la España republicana, me cortó la exposición para preguntarme cómo iban los frentes». ${ }^{34}$ Es decir, ataba su posicionamiento público a la suerte de los combates.

Tal vez como ninguna otra circunstancia, la representación de la guerra generó una grieta en el seno del catolicismo, que se extendió durante la posterior contienda mundial. Quien sintetizaba con mayor claridad los principios de la «guerra santa» fue el sacerdote argentino Julio Meinvielle (1905-1973), quien ya para esa época era un conocido redactor de la revista Criterio y había participado en los Cursos de Cultura Católica. ${ }^{35}$ Desde el inicio de la contienda española fue el más enragé de los intelectuales católicos argentinos, y tuvo la audacia de enfrentarse públicamente con Jacques Maritain - actividad a la que se dedicaría por el resto de su vida - , en un medio que era bastante medroso respecto de la cultura francesa. Otros, como su compañero César Pico - que también hizo públicas sus disidencias con Maritain - acompañó su famosa «carta abierta» al maestro con un pedido de disculpas en forma privada. ${ }^{36}$ Gustavo Franceschi, que sostuvo sus argumentos contra el francés, nunca alegó que sus ideas pudieran rozarse con la heterodoxia.

La filosofía de la historia de Menvielle estaba hecha de una lucha entre las voluntades contrastantes de Dios y de los hombres. Actores de un drama universal, las naciones - al estilo romántico - poseían personalidades propias. España y Francia eran los brazos de Roma, de la iglesia y de la cristiandad, por ende y sin mediaciones, de la acción de Dios en la tierra. Cuestionar o combatir a la iglesia implicaba rebelarse frente al altísimo. Tanto Francia como España, «hijas adoradas de la Iglesia», se ha-

34 «Cartas e informes cruzados entre el EBB y Manuel de Irujo, alusivos a los contactos del PNV con otras fuerzas políticas del exilio», (31 de mayo de 1951), Fondo Manuel Irujo (Caja 38, Clave 2798, Signatura J).

35 Sobre Meinvielle en los años de la Guerra Civil y la posguerra, véase Obregón, 2011 y Fares, 2017.

${ }_{36}$ Cesar Pico, otra de las figuras de los Cursos de Cultura Católica, le envió una «carta abierta» a Maritain criticando su posición frente a las organizaciones fascistas, que fue publicada y ampliamente difundida. Pico a Maritain, 10 de julio de 1937, Cercle d'Etudes Jacques \& Raïssa Maritain. 
bían apartado y rebelado contra ella, y en ese trance sobrevino su tragedia. España, que se había forjado en una tradición anti absolutista - en la cual la iglesia cumplía el papel de custodio de la ley evangélica - había iniciado su decadencia con el triunfo de los Borbones y luego, con el demo-liberalismo.

Una sociedad cristiana no era, para Meinvielle, una sociedad piadosa - en términos individuales o privados - sino una sociedad que respetaba las leyes de Dios en forma pública, que la iglesia tenía el mandato de custodiar. Rechazaba la idea - característica del anticlericalismo- que la buena fe se hallaba más fuera que dentro de la institución o que la salvación de las almas pudiera darse en una comunidad en la que la iglesia estuviera desligada del Estado. Por más apostolado católico, una sociedad no era parte de la cristiandad hasta que la religión no estructurara la vida política de la nación. Esa cristiandad estaba renaciendo en España con Franco y en Francia con Petain. Y ambas estaban llamadas a cumplir los roles de las «virtudes teologales». ${ }^{37}$ España tenía una función crucial, y cuando triunfara Franco, el nudo de la historia se habría desatado. Primero caería el demo-liberalismo y el comunismo, y finalmente el paganismo nazista. La cristiandad sería restaurada.

La violencia de la guerra no era, en ese marco, sólo un instrumento para la consecución de un fin justo: el triunfo de Dios sobre sus enemigos. Si así fuera, nos hablaría de una clara secularización de lo político en Meinvielle. Por el contrario, los sufrimientos de la guerra eran en sí una forma de conversión. El dolor purificaba, y los países, como los individuos, debían purgar sus pecados con la penitencia para reconvertirse. La mera represión exterior no era suficiente. La Guerra Civil era una verdadera guerra santa porque la lucha se entablaba en el campo teológico. No se luchaba simplemente por algo político o económico, ni siquiera por algo simplemente cultural o filosófico. Se luchaba por algo inmensamente superior como era el imperio de Cristo o del Anticristo. En oposición al neutralismo de Maritain, cuyas ideas podrían ser muy eficaces

...para convencer a almas sentimentales, y en el fondo destituidas de heroísmo, carece de valor porque se funda en la falsa hipótesis de que [sic] los españoles han acudido a las armas para implantar el reinado de Cristo Rey que no podían implantar por medios pacíficos. Los naciona-

37 Meinvielle, 1940. 
les españoles fueron a la guerra para reclamar con el último recurso que les quedaba a mano, el recurso de la espada, el derecho de vivir en el suelo español con la dignidad de hombres. ${ }^{38}$

Frente a los argumentos de Meinvielle, el humanismo cristiano elaboró una teología política alternativa. Su perfil se miraba en el espejo del nacionalcatolicismo para diferenciarse. Frente a la reivindicación de la violencia, proponía medios «apostólicos». Frente a los derechos de la iglesia, los derechos de la persona. Y finalmente, frente a la cristiandad restaurada, la nueva cristiandad. La Guerra Civil sirvió de escenario para plasmar estos desacuerdos de forma pública. No se trataba sólo de una toma de partido de carácter coyuntural. Para los católicos que no apoyaban a Franco la neutralidad o la opción pro-republicana implicó un alto costo público y personal.

En 1941, luego de estar desaparecido durante meses desde su huida de París, el presidente José Antonio Aguirre reapareció en Sudamérica y se trasladó a Buenos Aires, donde tuvo un recibimiento de jefe de estado. ${ }^{39}$ Un año después, ya asentando en Nueva York, realizó una gira por diversas capitales del continente. En Argentina su agenda fue muy intensa. Recorrió distintas organizaciones sociales, políticas y culturales de la comunidad vasca. Fue homenajeado en una cena por el Centro Republicano de Buenos Aires. Visitó el Centro Gallego, el Casal de Cataluña, el centro Orensano. Visitó radios y redacciones de diarios. Además de la capital, viajo a Córdoba y Rosario. Si bien se entrevistó con multitud de figuras de la sociedad civil, no tuvo contacto con representantes eclesiásticos. Es sabido que, en otros países de su gira, los nuncios y los obispos prohibieron a sus sacerdotes tener contacto con el lehendakari. Una excepción la constituyó la visita a la mediterránea provincia de Córdoba, donde fue recibido por el arzobispo Fermín Emilio Lafitte. «La entrevista con la primera autoridad eclesiástica de la provincia fue larga y cordial. El Dr. Aguirre se sintió resuelto y confortado, después de la entrevista, a exponer ante el público cordobés, especialmente de los católicos, su pen-

38 Meinvielle, 1937, p. 26.

39 «Llegamos a la siete de la mañana [...] Comienzan las visitas para mí y para Mary. Obsequios, afecto, emoción, entusiasmo. [...] Por la tarde visita al presidente Ortiz. Me recibe primero solo. Luego entran los demás. Me ha distinguido excepcionalmente. Afectuoso, cordial, gran amigo. [...] He visitado y me han recibido cordialmente los Expresidentes Alvear y General Justo...». Aguirre y Lecube, 1998, pp. 144-145. 
samiento», señalaba exultante Euzko Deya..$^{40}$ También visitó al obispo de Temnos, Miguel de Andrea, con quien conversó «sobre la situación del catolicismo en el mundo y del movimiento que es necesario realizar, para que los más altos valores espirituales salgan limpios de la catástrofe que conmueve al orbe». ${ }^{41}$

Días antes de su arribo a Buenos Aires, Aguirre dictó una conferencia en el teatro municipal de Santiago de Chile, donde habló de «La posición de un creyente ante la crisis de la caridad». En esa ocasión justificó la posición de los católicos españoles y, en particular, de los católicos vascos, en apoyo al gobierno de la República. El argumento de Aguirre se mantenía dentro de la ortodoxia, pero su gesto, implicaba un cuestionamiento de hecho a la autoridad religiosa. Por un lado, afirmaba que el episcopado español había mandado a respetar a la autoridad constituida hasta el 18 de julio de 1936. Y en cumplimiento de esa disposición los católicos españoles no tenían otra opción que obedecer a sus pastores. Recién en 1937 la jerarquía española se pronunció en la famosa Carta Colectiva del 1 de julio. Pero ese documento tenía para Aguirre una calidad diferente a los emanados durante la República. Basándose en las comunicaciones del mismo primado de España, Cardenal Gomá, se trataba de un documento de carácter histórico, de valor dogmático nulo y cuestionable capacidad disciplinar. En el fondo era un documento elaborado para ayudar a Franco y combatir la «propaganda adversa» que se hacía en un «gran sector de la prensa católica». Por eso, Aguirre cuestionaba los principales aspectos del documento, sosteniendo que no existía real peligro de triunfo comunista en España, que el país vasco era una demostración y que, en el caso de estar frente a una situación de desorden generalizado - como afirmaba la carta - , la misión de los cristianos era la de sostener al gobierno legítimamente establecido. Respecto de los violentos ataques que el clero y los edificios eclesiásticos sufrieron durante la República y al principio del alzamiento, Aguirre adoptaba una posición de condena, pero neutral. «Para hablar ajustándose a la verdad y a la caridad», sostenía, «hubiera sido más justo hablar de los excesos de ambas partes». En cualquier caso, y con un argumento que todos los defensores de la posición del nacionalismo vasco mencionarían, la situación religiosa en Euskadi antes, durante y después de la sublevación era radicalmente distinta del resto de España. Allí el

\footnotetext{
40 Euzko Deya, 30 de septiembre de 1942, p. 12.

${ }^{41}$ Euzko Deya, 10 de octubre de 1942, p. 3.
} 
culto siguió funcionando en forma habitual, los edificios habían sido preservados y el personal eclesiástico no había sido molestado. Por ello, y para justificar la posición de los católicos vascos, el presidente ponía en duda la legitimidad de las primeras admoniciones del obispo de Vitoria, Mateo Mugica: «demasiado conocía el prelado vasco de Vitoria quiénes éramos, y tanto nos conocía que hoy está en el exilio con nosotros». ${ }^{42}$

Una acusación era particularmente ponzoñosa para Aguirre: la de haber pactado con los comunistas. En ese punto, la justificación marcaba un salto desde el integralismo sabiniano a un nacionalismo secularizado. Para el presidente lo más importante era, en el contexto de la sublevación, salvar la tierra vasca de los invasores. Por sobre de las ideologías y las creencias, estaba el sentimiento nacional. La adhesión al estado dejaba en un segundo plano la adhesión a la fe. Las ideas demócrata cristianas de Aguirre se entremezclan con su esencialismo nacionalista: bajo el Árbol de la Guernica, atacado por el «campo de la anti libertad», se habían consagrado durante generaciones y bajos sus leyes «...nuestra vieja democracia». ${ }^{43}$ Por otro lado, Roma seguía siendo quien podía arbitrar en el conflicto en Euzkadi, otorgándole, al mismo tiempo que se lo quitaba al Episcopado español, una autoridad que relativizaba su propia autonomía política respecto del poder religioso. Nuncios, lobistas, representantes oficiosos del Vaticano aparecen en su relato como actores que convalidaron, en distintas oportunidades, la «correcta» postura de los vascos. Pero la mirada de Aguirre no era solo funcional, también tenía, al menos en términos discursivos, un carácter sustantivo. El cristianismo era incompatible, en su descripción, con los ataques a la libertad de los pueblos, a las dictaduras y los campos de concentración. En ese sentido, sin renunciar a la cristiandad, Aguirre adhería a instaurarla a través de los medios «apostólicos». ${ }^{44}$

En Buenos Aires, Aguirre se presentó en la Facultad de Filosofía y Letras. A fines de 1942 el clima político argentino estaba enrarecido. Había fallecido el presidente Ortiz y había asumido su conservador vicepresidente, Ramón Castillo, apoyado en los sectores nacionalistas del ejér-

42 Aguirre y Lecube, 1944, pp. 132-133.

43 Aguirre y Lecube, 1944, p. 142.

44 Aguirre rechazaba la neutralidad del estado liberal. En un pasaje de su conferencia en Chile afirmaba que «...como rector de esa comunidad que me dio su mandato, tengo no sólo el deber de procurar el bienestar material de mi pueblo, sino incluso el de atender y cuidar las preocupaciones del espíritu». Aguirre y Lecube, 1944, p. 137. 
cito, en un gobierno cada vez más autoritario, fraudulento y persecutorio. También había fallecido el principal líder de la oposición, Marcelo T. de Alvear, y en enero de 1943 moriría el expresidente - y figura tutelar del ejército- Agustín P. Justo, quien en sus últimas apariciones públicas había apoyado la causa de los Aliados en la guerra. De hecho, Aguirre y Justo almorzaron y se fotografiaron juntos en el vapor «Ciudad de Montevideo».

El tema que eligió Aguirre para su charla fue «El padre Vitoria visto por un vasco». Caracterizaba a Vitoria como un revolucionario, que había luchado contra los últimos restos del régimen feudal y se oponía al surgimiento del imperialismo moderno. La figura del sacerdote le servía para conectar el siglo XVI con el XX, en múltiples dimensiones. Su teología era antiabsolutista, en oposición a Sepúlveda, «el panegirista del poder imperial y digno antecesor de los modernos conquistadores y cruzados totalitarios». El cristianismo era para Vitoria una doctrina de fraternidad e igualdad entre todos los hombres y los pueblos, una base doctrinal «para una organización internacional cimentada en el respeto mutuo y en la convención entre iguales». ${ }^{45}$ Por otro lado, Vitoria era también el teólogo de la secularización. Aunque claro, no utilizaba ese término: Aguirre señaló que el filósofo cuestionó las prerrogativas pontificias en materias temporales, a las que oponía «el principio augusto de la libertad para la evangelización apartada de intereses materiales» ${ }^{46}$ Lo más interesante de la mirada de Aguirre sobre Vitoria era lo que hoy llamaríamos su «sociología de las ideas». Porque no era solo el corpus vitoriano lo que le interesa al presidente, sino que entrelazaba la vida del teólogo con los vaivenes políticos del siglo XVI. Aguirre hipotetizaba que buena parte de la reflexión de Vitoria debió ser el producto de su época y de las tensiones políticas de su medio. Al igual que Aguirre, Vitoria también fue perseguido por el emperador español. Y era su condición de vasco — «la influencia del lugar de nacimiento y la libertad política secular de sus compatriotas»- lo que determinaba su pensamiento. El hecho de haberse formado en un país con un «gobierno representativo y democrático», debió haber influido en la redacción que «el maestro de Salamanca» hizo de las cuestiones que atañían a la «soberanía de los pueblos y a la ilicitud de la conquista violenta». La guerra librada por el emperador contra la autonomía de Navarra

\footnotetext{
45 Aguirre y Lecube, 1944, p. 168.

46 Aguirre y Lecube, 1944, p. 170.
} 
habría hecho mella en el espíritu de Vitoria. «No creo», afirmaba Aguirre, «que sea imprudente sostener que Vitoria, el antimperialista cuando defendió a los indios, había defendido con anterioridad a sus compatriotas». La teología se volvía, en la mirada del lehendakari, una materia plástica, una reflexión que tomaba elementos de la realidad para componerse. Al igual que en la Guerra Civil, los tercios españoles se habían legitimado en una doctrina que «... comprometía la causa santa de la Religión en asuntos temporales». ${ }^{47}$ Los nuevos abusos totalitarios, las nuevas pretensiones del imperio español, necesitarían de una nueva teología que las combatiera. Un nuevo Francisco de Vitoria que, según especulaba Aguirre en su conferencia, «si hoy viviera, estaría en el exilio conmigo». ${ }^{48}$

Tanto en su visita de 1941 como en su más extensa gira por Sudamérica de 1942, Aguirre fue recibido en muchos casos como un verdadero jefe de estado, tributándosele los honores correspondientes. Esto generó la inquina de los representantes del gobierno de Franco que, en muchos casos, dejaron saber su molestia por los favores que recibió. Los uruguayos parecían los más hostiles a la causa de la Cruzada. Ernesto de la Orden, ex embajador en Uruguay, responsabilizaba a la mala influencia francesa en el Río de la Plata:

Nuestro catolicismo, anunciándolo de modo crudo, según las cosas que se recogen aquí o allá, se resiente nada menos que de ser anticristiano, es decir, opuesto a la esencia misma del cristianismo, que es la caridad; de ser político, íntimamente adherido siempre a una tendencia política, de ser antipopular, o sea, empeñado continuamente de desconocer la realidad de nuestro pueblo, en pretender dominarlo e imponerse sobre él. ${ }^{49}$

La culpa era de una «...circunstancia desgraciada y allí muy eficaz, que es el influjo de los vascos. Los vascos son en el Río de la Plata; en ambas orillas, la colectividad más respetada y más prestigiosa». Por eso «...la Hispanidad, por lo menos en la forma que se ha sólido entender aquí, no es allí demasiado grata. De una parte, porque han visto en ella

47 Aguirre y Lecube, 1944, p. 200.

48 Aguirre y Lecube, 1944, p. 210.

49 Ernesto de la Orden, «El catolicismo en el Uruguay. Penetración de las doctrinas de Maritain y Don Sturzo y graves censuras e incomprensiones para España», Asociación Católica Nacional de Propagandistas, 1 de diciembre de 1945, AN-EB13-85-3. 
una tendencia política concreta, antidemocrática, un contrabando ideológico que de ningún modo estaban dispuestos a tolerar».

Tanto en los argumentos esgrimidos por Aguirre, como por las críticas reseñada por De la Orden, es posible agrupar una serie de tópicos comunes. En esos años los dirigentes nacionalista vascos - con clara asesoría de sacerdotes, como el nacionalista Alberto Onaindia - produjeron una serie de textos que asistían a los polemistas en las disputas que mantenían con los representantes del catolicismo franquista. Algunos, por ejemplo, sirvieron de apoyatura para la querella pública entre José Antonio Aguirre y el cardenal primado de España, Isidro Gomá y Tomá. ${ }^{50}$ En el archivo de Pedro de Basaldúa se guarda un documento de carácter político-teológico, destinado a refutar los principios que justificaban - a vistas de la opinión católica internacional - el alzamiento del 18 de julio de $1936 .{ }^{51}$ Los argumentos citados en dicho manuscrito no difieren de los que los nacionalistas vascos hacían circular en esos años. Su estilo era aún de tipo jurídico catequético, con el formato de una típica disputatio inserta en el modelo escolástico. Sin embargo, con viejas herramientas los nacionalistas intentaban crear un modelo nuevo. Para demostrarlo utilizaba como insumo $-\mathrm{y}$ en forma estratégica - una sobreabundante teología política del siglo XIX, de carácter profundamente contrarrevolucionario, y defensora del statu quo. El documento contenía dos importantes argumentos. La sublevación era ilícita frente a las enseñanzas de los romanos pontífices, los santos padres, las santas escrituras, la teología española y el mismísimo episcopado español. Incluso si se supusiera que el gobierno de la República era ilegítimo, incluso si se hubiera instaurado el comunismo, la solución nunca era la violencia, si no la palabra de Dios, «...el método de los Apóstoles, que de esa manera conquistaron el mundo». Por el contrario, los sublevados defendían una teología guerrera. «Benditos sean los cañones si las brechas que abren, florece el Evangelio» había afirmado el Obispo de Cartagena. Para el autor del documento se trataba de la demostración de que «la guerra nacional española es una guerra sacrílega».

El segundo argumento se refería a la posición de los vascos frente a la sublevación. En particular, el documento cuestionaba a quienes desde la Cruzada los acusaban de aliarse al comunismo. La defensa nacional, en

50 Aguirre y Lecube, 1938. Sobre la polémica, véase Meer, 1987; Núñez Rivero, 2017. Sobre la labor de Onaindia, véase Arrieta Alberdi, 2019.

51 Basaldúa, Pedro de, «La sublevación española y los vascos ante las doctrinas de la Iglesia», AN. PNV-EBB, K.00369, C.3. 
este caso, estaba por encima de las diferencias ideológicas. Por principio todos tienen derecho de defenderse contra quienes injustamente los atacan con armas. Y no podían cooperar contra una sublevación que era ilícita. No estaban obligados en conciencia porque era «gravemente injusta e ilícita. Los vascos se defendieron de un injusto agresor que venía a destruir su patrimonio espiritual, arrancar sus raíces raciales, y sujetarlas a la ignominiosa esclavitud». El documento no hacía una defensa del derecho de los vascos a la autodeterminación, ni tomaba - como sí hizo Aguirre en su polémica con Gomá- la cuestión social como un argumento para impugnar a sus opositores. Se trataba de una defensa estrictamente religiosa.

En la práctica, el documento reiteraba una crítica contra los obispos «españoles». Si bien se declaraba obediente al magisterio, era selectivo respecto de qué aspectos u órdenes estaba dispuestos a obedecer. «...tenemos un grandísimo respeto por los Obispos de cualquier Nación» afirmaba, «...pero mayor respeto a la verdad y las doctrinas de la iglesia. [...] no tememos afirmar que se han equivocado los Obispos que han declarado lícita y justa esa sublevación. [...] La Iglesia es infalible, no los Obispos de una Nación». En forma significativa, el documento mostraba los límites de la teología tomista. Una crítica coincidente con los ensayos que la nouvelle theologie realizaba desde fines de la década de 1930:

[...] ... Por desgracia los teólogos de la época escolástica han incurrido en un gravísimo error: se fundan en los principios de razón más que en principios de fe. El mismo S. Tomás no está exento de esta tendencia a argumentar especialmente con principios de razón. Y como los principios de razón no son los principios de la teología, de ahí que la Teología no haya [hecho] notables progresos después del siglo XVI. La razón se engaña fácilmente, en particular cuando se trata de materias reveladas; la fe es infalible, porque [está] fundada en la palabra infalible de Dios infaliblemente expuesta por la Santa Madre Iglesia. Con íntima satisfacción vemos que no pocos teólogos modernos, abandonando inútiles disputas escolásticas, se dan de lleno al estudio de doctrinas reveladas. Es lo que nosotros hemos hecho en las secciones precedentes. ${ }^{52}$

La cita de este extenso párrafo se justifica, dado que los actores eran conscientes de la necesidad de producir una nueva vinculación entre prin-

52 Basaldúa, Pedro de, «La sublevación española...», op. cit. s.pag. Sección cuarta. «La teología católica condena la sublevación española». 
cipios religiosos y prácticas políticas. La «vuelta a las fuentes» evangélicas era una forma de rechazar el juridicismo de la teología que venía de Roma.

Del integralismo de los primeros años del PNV, la dirigencia vasca pasó a proponer una laicidad negociada. ${ }^{53}$ Por supuesto, en el exilio convivían miradas muy diversas respecto de esta relación, y una militancia que superponía lo político y lo religioso, sin solución de continuidad. Es por eso que, llegado a la Argentina, Basaldúa no se sorprendía ni cuestionaba el hecho de ser convocado por algunas figuras del Episcopado o que, a lo largo de la década de 1940 y 1950, considerara natural - dentro de su acción político-comunitaria en Argentina - tratar de influir en la cultura católica. Pero las tensiones entre el modelo integralista y el del humanismo cristiano se expresaron al interior de la dirigencia del nacionalismo vasco. En 1951 Irujo se quejaba frente al EBB de la publicación de un artículo del Ceferino de Jemein en la revista Alberdi, editada en Bayona, en el que se afirmaba la «irrevocabilidad» de los principios del PNV, la herencia de Sabino Arana, un partido que era «personalmente suyo». En particular, Irujo se irritaba frente a la afirmación de una doctrina «que plantea una completa e incondicional subordinación de lo político a lo religioso, del Estado a la Iglesia». Esto era inconcebible, refutatorio de los principios «demócratas» que el partido debía defender. «Si este texto fuera reproducido por cualquier contradictor nuestro, pudiera servir en sus manos para acreditar que nuestras bases doctrinales son las mismas o similares a las de Franco». .4

53 Con el concepto de «laicidad negociada» nos referimos a la brecha que abre la postura de Maritain en el mundo católico con su idea de una «nueva cristiandad». El ciclo iniciado con la encíclica Quanta cura y el Syllabus en 1864, negaba cualquier negociación posible entre el poder civil y la iglesia de Roma. En la propuesta LXXX se rechazaba que «El Romano Pontífice puede y debe reconciliarse y transigir con el progreso, con el liberalismo y con la moderna civilización». Por el contrario, en $\mathrm{Hu}$ manismo Integral y luego en El hombre y el Estado, Maritain reconoce el fin de la sociedad sacra, y la necesidad de construir un estado que se ajuste a la diversidad de familias espirituales. Detrás de la nueva cristiandad aparece una nueva laicidad, diferente a la que habían encarado muchos gobiernos europeos del siglo XIX, de tono anticlerical. Véase Maritain, 1936; Maritain, 1952.

${ }^{54}$ Irujo al EBB, 11 de febrero de 1951, p. 71. Fondo Manuel Irujo (Caja 38, Clave 2798, Signatura J). 
Basaldúa debió confrontar esos dos modelos cuando, durante el exilio, decidió escribir la biografía de Sabino Arana y Goiri. ${ }^{55}$ José Antonio Aguirre, enterado del proyecto le advertía:

No quiero dejar pasar el darte una impresión personal, y si me lo admites un consejo a este respecto, es a saber, que en Arana Goiri es más importante la línea central de su pensamiento que podría en lenguaje moderno denominarse demócrata cristiano, que todo lo demás. [...] Anticipadamente se fijó en el problema social. Fustigó a los poderosos del tiempo; siguió fiel a la eterna tradición demócrata, y si en el orden de las relaciones político-religiosas se le puede inculpar, mirando a las cosas desde nuestros días, de un poco de integrismo, es menester examinar a Arana Goiri completamente de acuerdo a Maritain, y enfrente, fieramente enfrente de las doctrinas de violencia integral española, o de los integrismos totalitarios del resto del mundo. ${ }^{56}$

Resultaba claro que Aguirre buscaba construir una memoria en la que el legado de Arana se ensamblara con la nueva perspectiva político-religiosa del PNV: democracia cristiana, personalismo y socialcristianismo. En este último aspecto, el humanismo cristiano tomó nota del ingreso de las masas y el conflicto social al problema del orden político. Su distinción del liberalismo - al que acusaba de individualista - le permitía optar por una propuesta de orden económico - más idealmente planteada que efectivamente realizada - que implicaba un liberismo atemperado, en donde la iniciativa privada tenía un papel central, que se combinaba con recelos hacia la libertad de mercado absoluta, en particular cuando se trataba de las relaciones laborales. El liberismo económico se fraguaba con el profundo anticomunismo de la dirigencia vasca de entreguerras, característica que se fue acentuando a medida que la Guerra Fría se profundizó y se expandió por América Latina. Basaldúa escribió, un año después de que el gobierno revolucionario de Cuba declarara su carácter socialista, La garra comunista en América Latina.$^{57}$ Fue editado por la Asociación Argentina por la Libertad de la Cultura, filial del Congreso por la Libertad de la Cultura, una organización internacional financiada por las agencias de seguridad norteamericanas para contrarrestar el espacio que ganaba la cultura de izquierda entre los in-

\footnotetext{
55 Basaldúa, 1953.

56 Carta de Aguirre. 8 de enero de 1953. AN-GE-654-1.

57 Basaldúa, 1962.
} 
telectuales latinoamericanos y europeos..$^{58}$ Para Basaldúa el atractivo de las ideas de izquierda entre los jóvenes - incluso vascos - era uno de los principales peligros. ${ }^{59}$

El proceso de adopción de los principios demócrata cristianos tuvo entre 1936 y 1941 un momento clave. La decisión del nacionalismo vasco de participar en el bando republicano - por más que se tratara de una medida a desgano y que no implicó a todos los territorios históricos - no fue el producto de un mero cálculo político, dado que, en un partido tan cruzado por el catolicismo, era al menos necesario contar con un discurso religioso en el que volcar esa decisión. ${ }^{60}$ La experiencia de la Guerra Civil, las negociaciones con el resto de los partidos republicanos, y en especial los argumentos que los nacionalistas vascos $-\mathrm{y}$ sus amigos - debieron desplegar para combatir a sus enemigos dentro del catolicismo, los convenció - si es que no lo estaban hasta ese momento- de una serie de tópicos en torno a los cuales podían hacer inteligible para ellos y para el resto de los católicos del orbe semejante determinación. ${ }^{61}$ Con la reaparición de Aguirre en 1941, la recomposición del gobierno vasco en el exilio, así como la colaboración con las agencias norteamericanas, se abre una nueva etapa, con el refinamiento de los tópicos del humanismo cristiano durante la Segunda Guerra y la inmediata posguerra, con la singula-

58 Janello, 2015.

59 En correspondencia con José Ramón de Zubizarreta le indicaba que «De ninguna manera nos conviene mezclar nuestro movimiento y nuestros centros con organizaciones extrañas aun cuando estas fueran de carácter democrático. Aquí en la Argentina mantenemos una separación completa y lo mismo sucede en el resto de los países americanos, así como en Francia. Podemos sí mantener relaciones cordiales con los republicanos españoles en la lucha contra Franco pero siempre que esas relaciones y compromisos que pudieran establecerse quede bien claro que nuestra lucha definitiva es la libertad de Euskadi. Podemos coincidir en la acción de la causa común antifranquista pero no con organizaciones o movimientos o actos que puedan tener el menor matiz comunista [...] Debemos actuar como vascos exclusivamente sin uniones permanentes, sin mezcolanzas sin confusionismos». Basaldúa a José Ramón de Zubizarreta, ca. 1960. AN-GE-654-1.

${ }^{60}$ Leyre Arrieta Alberdi sostiene esta posición, señalando que la decisión de apoyar al bando republicano «no fue aleatoria» y que la evolución ideológica del PNV «se tradujo en una constante identificación entre nacionalismo, catolicismo y democracia». Véase Arrieta Alberdi, 2018.

${ }^{61}$ Respecto a la relevancia del caso vasco durante la guerra civil, señala Fernando de Meer: «Tanto para los gobiernos de otros países, y en particular para la Santa Sede, como para la opinión pública internacional y, en especial para la católica, el «caso vasco» fue un elemento de juicio ineludible a la hora de valorar lo que ocurría en España». Véase Meer, 1989, p. 117. 
ridad de articular el liberalismo y el cristianismo, en oposición a quienes veían con simpatía un triunfo del Eje. En especial, dentro de la cultura católica argentina esta posición de franca defensa - política, pero también ideológica - de los Aliados implicaba poner en cuestión la estrategia neutralista de Roma, que los obispos argentinos seguía con obediencia y también con convicción. La decepción del exilio republicano $-\mathrm{y}$ vasco- en la posguerra, con la recomposición de las relaciones entre Estados Unidos y España, fue un catalizador para la afirmación doctrinaria democristiana del PNV y de su vocación europeísta. ${ }^{62}$

\section{Conclusión}

¿Cómo y por qué los nacionalistas vascos se hicieron demócratas cristianos? Las fuentes citadas permiten afirmar que el nacionalismo vasco de la generación de 1936 se separó del nacionalcatolicismo por mucho más que una cuestión meramente político coyuntural centrada en el estatuto de autonomía y el consiguiente apoyo a la República. Llegaron a esa decisión -y la profundizaron - luego de una experiencia de fricciones intra-religiosas de las cuales sobrevendría un replanteamiento del papel que debía ocupar la iglesia y la religión en la sociedad. No se trató solo de la «influencia» o la «absorción» por parte del nacionalismo vasco - como de otros grupos católicos argentinos - de las ideas que desarrollaron los intelectuales católicos franceses y belgas durante las entreguerras, sino que fue el producto de una construcción propia. Sin duda la circulación de figuras tutelares - como Maritain o Mounier - funcionó como un pilar de legitimidad en las encarnizadas disputas de esos años. Pero debe combinarse con los viajes físicos e intelectuales de un conjunto diverso de figuras y referentes, que terminó cristalizando en una nueva teología política. Sin duda, su colaboración con distintos grupos antifascistas fue clave para catalizar esta mutación.

En sus orígenes, el nacionalismo vasco adhería a ideas que manaban del torrente integralista. La autonomía de Euskadi era un medio, y no un fin, para preservar un bien superior: la salvación del alma cristiana de los vascos, impidiendo que se contamine con la heterodoxia de los españoles. Este «ascetismo etno-mundano» suponía que manteniendo la pureza cultural se podría acceder a los bienes de salvación. Una posición elitista, tí-

62 Goiogana, Irujo Ametzaga, y Legarreta, 2007; Arrieta Alberdi, 2007; Arrieta Alberdi, 2019. 
picamente sectaria, en los términos de Weber y Troeltsch: los incluidos en la comunidad formaban un colectivo de salvados ${ }^{63}$ Esta idea de superioridad étnico-religiosa (frente a la «corrupción» de los foráneos) puede ser un plafón desde el que puede pensarse el lugar de enunciación de una teología política demócrata cristiana. Al punto que el presidente Aguirre, un laico empoderado, se sintió con la capacidad de enseñarle moral cristiana al cardenal primado Isidro Gomá.

Tratándose de un partido de origen integralista, en el que política y religión se superponían en forma natural, fue consecuente que el avance hacia una secularización de su discurso se produjera a través de una nueva teología. Ésta se volcó en el molde del humanismo cristiano de la segunda posguerra. Y era el producto de las tensiones intrareligiosas de esos años, en los que se abrió paso una tercera vía entre los restauradores, al estilo de Julio Meinvielle, que aspiraban a reponer la Cristiandad medieval, y los católicos liberales, para quienes la religión y la iglesia poco tenían que decir en la esfera pública. Una nueva laicidad emergía como la expectativa de las democracias cristianas de los años de 1950.

Mientras se reunía el congreso de Pax romana, que daría el puntapié para el lanzamiento del Instituto de cultura hispánica, se congregaban en Europa y Sudamérica representantes de grupos demócrata cristianos con el objeto de construir redes de acción común. Dentro del catolicismo político se consolidaban identidades originadas en las mismas fuentes, pero de características cada vez más opuestas. La democracia cristiana en los años cuarenta no era un proyecto consolidado y trasparente, una ideología que estaba esperando ser «adoptada». Los procesos políticos europeos de entreguerras y la Segunda Guerra fueron los que catalizaron una reflexión teológica que habilitó un nuevo programa político. El nacionalismo vasco jugó un papel preponderante en ambas orillas del Atlántico.

El exilio vasco en Argentina cruzó los conflictos europeos étnicoreligiosos con la coyuntura sudamericana. Se trataba de una región en

${ }^{63}$ En la primera edición de La ética protestante y el espíritu del capitalismo (19041905), Weber analiza las sectas como grupos formados únicamente por los verdaderos fieles. En la edición de 1920 aclara que Troeltsch «...ha solucionado mucho mejor lo que había de explicar de una manera que, no siendo teólogo, no habría podido». Troelsch en su The Social Teaching of the Christian Churches de 1912, agrega que la secta busca asegurar una hermandad personal y directa entre sus miembros, caracterizándose por el rechazo a la sociedad que los rodea, protagonizando una forma de oposición a las instituciones sociales establecidas. Véase Weber, 2011; Troeltsch, 1992. 
proceso de violenta transformación, en la que las tensiones de la sociedad de masas se manifestaron en el plano político. La confrontación fascismo - antifascismo fue estructurante en los años inmediatos a la Segunda Guerra, y con la llegada del peronismo al poder en 1946 este clivaje no hizo más que actualizarse y prolongarse en el tiempo, incluso más allá de su vigencia en el viejo continente. El peronismo les dio a los exiliados vascos un ejemplo muy próximo de la convivencia perturbadora entre estado, iglesia y sociedad. Aunque, claro está, el justicialismo nunca alcanzó los niveles de compromiso a los que arribó el régimen de Franco en España, y su deriva discursiva terminará, en 1955, en el enfrentamiento más violento del siglo XX entre la iglesia y el estado argentino. El ciclo peronista - bajo el cual los exiliados vascos fueron vigilados, en principio, para luego ser testigos de esta final ruptura entre Perón y sus antiguos aliados clericales e hispanófilos - fue otra importante experiencia de la segunda posguerra que exorcizó a los nostálgicos de la cristiandad.

Teniendo en cuenta esta relación espejada entre Franco y Perón, sin duda y al menos en un aspecto Julio Meinvielle parece no haberse equivocado: España desató el nudo de la historia. No el que ataba la modernidad, pero sí el que ataba a la Iglesia y al catolicismo a un modelo de relaciones que sólo podía ir del integralismo a la exclusión, es decir, de la cristiandad intolerante o la laicidad novecentista. El modelo español mostraba lo anacrónico de la cristiandad en un mundo en donde se reconfiguraban rápidamente las relaciones entre política y religión.

\section{Fuentes}

Eusko Ikaskuntza - Sociedad de Estudios Vascos. Fondo Manuel Irujo (MI).

Cercle d'Etudes Jacques \& Raïssa Maritain (CEJRM).

Archivo del Nacionalismo Vasco. Fundación Sabino Arana (AN).

Euzko Deya (Buenos Aires).

\section{Bibliografía}

ABELLÁN, José Luis y MONCLÚS, Antonio, El Pensamiento español contemporáneo y la idea de América: El pensamiento en España desde 1939, Anthropos Editorial, Barcelona, 1989.

AGUIRRE Y LECUBE, José Antonio, Cinco conferencias pronunciadas en un viaje por América, Ekin, Buenos Aires, 1944. 
AGUIRRE Y LECUBE, José Antonio, Diario de Aguirre, Txalaparta, Bilbao, 1998.

AGUIRRE Y LECUBE, José Antonio, Le problème basque. Vu par le cardinal Goma et le président Aguirre, Grasset, París 1938.

ÁLVAREZ GILA, Óscar, «El exilio en la conformación del clero argentino. El caso vasco (1840-1940)», Archivum, XVI, 1994; pp. 241-261.

ÁLVAREZ GILA, Óscar, «La vinculación entre clero e inmigración vasca en Argentina: razones y formas», Hispania Sacra, 50, 102, 1998a, pp. 557-587.

ÁLVAREZ GILA, Óscar, «La nonata "Sección Vasca” del Congreso Eucarístico de Buenos Aires (1934)», Archivum, XVIII, 1998b; pp. 421-430.

ÁLVAREZ GILA, Óscar, «Clero vasco y nacionalismo: del exilio al liderazgo de la emigración (1900-1940)», Studi Emigrazione/Migration Studies, XXXVI, 113, 1999, pp. 101-118.

ARRIETA ALBERDI, Leyre, Estación Europa: la política europeísta del PNV en el exilio (1945-1977), Tecnos, Madrid, 2007.

ARRIETA ALBERDI, Leyre, «El Nacionalismo Vasco y Jacques Maritain (1936-1945)», Ayer, 113, 2019, pp. 189-215.

ARRIETA ALBERDI, Leyre, «Dilemas del nacionalismo vasco en la Guerra Civil», en VALERO GÓMEZ, Sergio y GARCÍA CARRIÓN, Marta (ed.), Desde la capital de la República: Nuevas perspectivas y estudios sobre la Guerra Civil, Valencia, Universitat de Válencia, 2019, pp. 171-188.

BASALDÚA, Pedro de, Con los alemanes en París: páginas de un diario, Ekin, Buenos Aires, 1945.

BASALDÚA, Pedro de, El Libertador vasco Sabino de Arana Goiri: biografía histórica (con prólogo de José Antonio Aguirre), Buenos Aires, Ekin, 1953.

BASALDÚA, Pedro de, La garra comunista en América Latina, Asociación Argentina por la Libertad de la Cultura, Buenos Aires, 1962.

BELLAH, Robert y N. HAMMOND, Phillip E., Varieties of Civil Religion, Wipf and Stock Publishers, Eugene, 2013.

BISSO, Andrés, Acción argentina: un antifascismo nacional en tiempos de guerra mundial: acción argentina y las estrategias de movilización del antifascismo liberal-socialista en torno a la segunda guerra mundial, 1940-1946, Prometeo Libros, Buenos Aires, 2005.

BOTTI, Alfonso, «La iglesia vasca dividida: cuestión religiosa y nacionalismo a la luz de la nueva documentación vaticana», Historia contemporánea, 35 , 2007, pp. 451-489.

BROWN, Callum G., Religion and society in twentieth-century Britain, Pearson Longman, Harlow, 2006.

CAÑELLAS MAS, Antonio, «Las políticas del Instituto de Cultura Hispánica. 1947-1953 », Historia Actual Online, 33, 2014, pp. 77-91.

COMPAGNON, Olivier, Jacques Maritain et l'Amérique du sud: le modèle malgré lui, Presses universitaires du Septentrion, Villeneuve-d'Ascq, 2003. 
La teología política de la secularización. Pedro de Basaldúa y el exilio vasco en Argentina

DELGADO, Manuel, El espacio público como ideología, Libros de la Catarata, Madrid, 2015.

DEVOTO, Fernando, «Atilio Dell'Oro Maini. Los avatares de una generación de intelectuales católicos del centenario a la década de 1930», Prismas. Revista de Historia Intelectual, 9, 2009, pp. 187-204.

FARES, María Celina, «Por los sinuosos senderos del catolicismo integralista. Una biografía de Juan Ramón Sepich Lange», en GOMES, Gabriela y VICENTE, Martín (comp.). Trayectorias de Intelectuales en el Estado. Actas de Jornadas de discusión, UNGS, Los Polvorines, 2016.

FARES, María Celina, «Las caras del hispanismo: tránsitos y perfiles de intelectuales de derecha en la posguerra», Nuevo Mundo Mundos Nuevos. Nouveaux mondes mondes nouveaux - Novo Mundo Mundos Novos - New world New worlds, 6 de junio de 2017, [En línea], Consultado 25 de abril 2018. URL: http://journals.openedition.org/nuevomundo/70537.

GENTILE, Emilio, Politics as religion, Princeton University Press, Princeton 2006.

GOIOGANA, Iñaki, IRUJO AMETZAGA, Xabier, y LEGARRETA Josu, Un Nuevo 31: Ideología y estrategia del gobierno de Euzkadi durante la Segunda Guerra Mundial a través de la correspondencia de José Antonio Aguirre y Manuel Irujo, Sabino Arana Fundazioa, Bilbao, 2007.

GONZÁLEZ CUEVAS, Pedro Carlos, Maeztu: biografía de un nacionalista español, Marcial Pons, Madrid, 2003.

GONZÁLEZ CUEVAS, Pedro Carlos, El pensamiento político de la derecha española en el siglo XX: de la crisis de la restauración al estado de partidos (1898-2000), Tecnos, Madrid 2005.

HALPERÍN DONGHI, Tulio, La Argentina y la tormenta del mundo: ideas $e$ ideologías entre 1930 y 1945, Siglo Veintiuno Argentina, Buenos Aires, 2004.

HERVÁS, Alfonso Galindo, «Por una política sin teología política», Revista Pléyade, 8, 2011, pp. 171-183.

IANNINI, Nicolás, «Sol y Luna: una revista nacionalista-católica en el contexto de los años '30 y '40. Una definición al interior del mundo católico y del nacionalismo de derecha respecto del hispanismo, de la Guerra Civil española, del franquismo y del fascismo», Anuario del Centro de Estudios Históricos «Prof. Carlos S. A. Segreti», 13, 2013, pp. 155-174.

IANNINI, Nicolás, «Entre dos guerras. Juan Carlos Goyeneche y la definición de una identidad y de un proyecto para la nación», PolHis. Revista Bibliográfica del Programa Interuniversitario de Historia Política, 12, 2015 , pp. 141-174.

JANELLO, Karina, «La intelectualidad liberal bajo la Guerra Fría: La sede argentina del Congreso por la Libertad de la Cultura (1953-1964)», Acta Sociológica, 68, septiembre-diciembre 2015, pp. 9-47. 
JIMÉNEZ DE ABERASTURI CORTA, Juan Carlos, De la derrota a la esperanza: políticas vascas durante la segunda guerra mundial (1937-1947), Instituto Vasco de Administración Pública, Vitoria, 1999.

KLICH, Ignacio y RAPOPORT, Mario, Discriminación y racismo en América Latina, Grupo Editor Latinoamericano, Buenos Aires 1997.

LIDA, Miranda, y FABRIS, Mariano (eds.), La revista Criterio y el siglo XX argentino. Religión, cultura y política, Prohistoria Ediciones, Buenos Aires, 2019.

LÓPEZ SÁNCHEZ, José María, Los refugios de la derrota: el exilio científico e intelectual republicano de 1939, Consejo Superior de Investigaciones Científicas, Madrid, 2013.

LOUZAO VILLAR, Joseba, Soldados de la fe o amantes del progreso: catolicismo y modernidad en Vizcaya (1890-1923), Genueve Ediciones, Palma de Mallorca, 2011.

LOUZAO VILLAR, Joseba y MOLINA APARICIO, Fernando, «El pluralismo vasco: política e historiografía», Historia y política: Ideas, procesos y movimientos sociales, 32, 2014, pp. 301-328.

LOUZAO VILLAR, Joseba, «El Síndrome de Jerusalén: ¿la religión y los vascos?» en MOLINA, Aparicio Fernando y PÉREZ PÉREZ, José Antonio, El peso de la identidad: mitos y ritos de la historia vasca, (eds.), Marcial Pons, Madrid, 2015, pp. 81-107.

MARITAIN, Jacques, Humanisme Integral, Aubier, Paris 1936;

MARITAIN, Jacques, El hombre y el estado, Editorial Kraft, Buenos Aires, 1952.

MARTÍNEZ RUEDA, Fernando, «Religión y nacionalismo vasco en el siglo xx: aproximación desde el sujeto a una relación compleja», Hispania Sacra, 69, 140, 2018, pp. 721-733.

MCGEE DEUTSCH, Sandra, «Mujeres, antifascismo y democracia: La Junta de la Victoria, 1941-1947», Anuario IEHS: Instituto de Estudios histórico-sociales, 28, 2013, pp. 157-175.

MEER, Fernando de, «Una carta de José Antonio Aguirre al cardenal Gomá ( 9 de marzo de 1937). Nota documental», Boletín de la Real Academia de la Historia, 184, 3, 1987, pp. 521-562.

MEER, Fernando de, «Algunos aspectos de la cuestión religiosa en la guerra civil (1936-1939)», Anales de Historia Contemporánea, 7, 1989, pp. 111-126.

MEER, Fernando de, El Partido Nacionalista Vasco ante la guerra de España (1936-1937), EUNSA, Pamplona, 1992.

MEIER, Heinrich, «¿Qué es la teología política? Introducción a un concepto controvertido», La torre del Virrey, revista de estudios culturales, 6, 2009, pp. 89-93.

MEIER, Heinrich, Leo Strauss y el problema teológico-político, Katz, Buenos Aires, 2006. 
La teología política de la secularización. Pedro de Basaldúa y el exilio vasco en Argentina

MEINVIELLE, Julio, Qué saldrá de la España que sangra, Talleres Gráficos San Pablo, Buenos Aires, 1937.

MEINVIELLE, Julio, Hacia la cristiandad: apuntes para una filosofía de la historia, Adsum, Buenos Aires, 1940.

MONOD, Jean-Claude, La querelle de la sécularisation: théologie politique et philosophies de l'histoire de Hegel à Blumenberg, Vrin, París, 2002.

MONTERO GARCÍA, Feliciano; CUEVA MERINO, Julio de la; y LOUZAO VILLAR, Joseba, La historia religiosa de la España contemporánea: balance y perspectivas, Universidad de Alcalá/Servicio de Publicaciones, Alcalá, 2017.

NOSETTO, Luciano (ed.), Lecturas de Carl Schmitt. Forma y contenido de la teología política, Instituto de Investigaciones Gino Germani (IIGG/UBA), Buenos Aires, 2014.

NÚÑEZ RIVERO, Cayetano, La Iglesia y la política española 1931-1978. La Segunda República y el franquismo, Dykinson, Madrid, 2017.

OBREGON, Martin, «Catolicismo integral, identidad nacional y masas populares: Una aproximación a la trayectoria intelectual de Julio Meinvielle y Gustavo Franceschi (1930-1955)», en VIII Jornadas de Investigación en Filosofía. Universidad Nacional de La Plata, La Plata, 2011.

PABLO, Santiago de y Mees, Ludger, El péndulo patriótico: historia del Partido Nacionalista Vasco, 1895-2005, Crítica, Barcelona, 2005.

PATTIN, Sebastián, «Guerra española, guerra santa: apuntes a partir de una controversia conceptual en Argentina (1936-1937)», Historia Contemporánea, 60, 2019, pp. 619-646.

PICO, César E., Carta a Jacques Maritain sobre la colaboración de los católicos con los movimientos de tipo fascista, Adsum, Buenos Aires, 1937.

PRADO, Gustavo H., Rafael Altamira en América, 1909-1910: historia e historiografía del proyecto americanista de la Universidad de Oviedo, Editorial CSIC - CSIC Press, Madrid, 2008.

PUHLE, Hans-Jürgen, «Baskischer Nationalismus im spanischen Kontext», Geschichte und Gesellschaft. Sonderheft, 8, 1982, pp. 51-81.

REIN, Raanan, Entre el abismo y la salvación: el pacto Franco-Perón, Lumiere/ Universidad de Tel Aviv, Buenos Aires/Tel Aviv, 2003.

SAN SEBASTIÁN, Koldo, El exilio vasco en América, 1936-1946: la acción del gobierno: política, organización, propaganda, economía, cultura, diplomacia, Txertoa, San Sebastián, 1988.

SANZ GOIKOETXEA, Eneko y ÁLVAREZ GILA, Óscar, «La delegación vasca de Buenos Aires (1938-1982)», Guregandik, 6, 2010.

SCHMITT, Carl, Teología política, Trotta, Barcelona, 2009 (1922).

SCHMITT, Carl, Catolicismo y forma política, Barcelona, Tecnos, 2001 (1923).

SCHWARZSTEIN, Dora, Entre Franco y Perón: memoria e identidad del exilio republicano español en Argentina, Crítica, Barcelona, 2001. 
SEPICH, Juan, «Introducción al tema cuarto: «El universitario católico ante los problemas del Estado moderno», en XIX Congreso Mundial de Pax Romana, Madrid, 1946.

TROELTSCH, Ernst, The Social Teaching of the Christian Churches, John Knox Press, Westminster, 1992 (1912).

TUSELL, Javier, Franco y los católicos: la política interior española entre 1945 y 1957, Alianza, Madrid, 1984.

WEBER, Max, La ética protestante y el espíritu del capitalismo, Fondo de Cultura Económica, México, 2011.

ZAMAGNI, Gianmaria, «Friede, Martyrium, Christenheit Theologische Modelle Im Spanischen Bürgerkrieg» en SILKE, Hensel y WOLF, Hubert (ed.), Die Katholische Kirche Und Gewalt: Europa Und Lateinamerika Im 20. Jahrhundert, Colonia, Böhlau Verlag, 2013, pp. 31-58.

ZAMAGNI, Gianmaria, «“¡Viva España! ¡Viva Cristo Rey!”. Das Spanische Bischofsamt Und Der Bürgerkrieg» en PERIN, Raffaella, Pio XI Nella Crisi Europea: Atti Del Colloquio Di Villa Vigoni, 4-6 Maggio 2015, Venecia, Edizioni Ca' Foscari, 2016, pp. 177-190.

ZANATTA, Loris, Del estado liberal a la nación católica: iglesia y ejército en los orígenes del peronismo, 1930-1943, Universidad Nacional de Quilmes, Buenos Aires, 1996.

ZANATTA, Loris, «De faro de la Hispanidad a Centinela de Occidente. La España de Franco en América Latina entre la Segunda Guerra Mundial y la Guerra Fría», Anuario IEHS: Instituto de Estudios histórico-sociales, 23, 2008, pp. 47-73.

ZANCA, José, «Ni un árbol donde ahorcarse. El exilio vasco y el humanismo cristiano en Argentina», Estudios Migratorios Latinoamericanos, 64, 2009, pp. 485-511.

ZANCA, José, «Jacques Maritain en Buenos Aires: la cita envenenada» en BRUNO, Paula (Coord.), Visitas culturales. Argentina, 1890-1930, Ed. Biblos, Buenos Aires, 2014.

ZANCA, José, «Euskal Herria en Buenos Aires. El exilio vasco en las páginas de Orden Cristiano», Anuario IEHS, 29-30, 2014-2015, pp. 289-302.

\section{Financiación}

Este trabajo forma parte de los resultados del proyecto «La patria hispana, la raza latina. Intelectuales, identidades colectivas y proyectos políticos entre España, Italia y Argentina (1880-1945)», financiado por el Ministerio de Industria, Economía y Competitividad (HAR2016-75324-P). 
La teología política de la secularización. Pedro de Basaldúa y el exilio vasco en Argentina

\section{Datos del autor}

José Zanca es profesor de Historia por la Universidad de Buenos Aires, Magíster en Investigación Histórica y Doctor en Historia por la Universidad de San Andrés. Es investigador adjunto del CONICET (Consejo Superior de Investigaciones Científicas y Tecnológicas). Es miembro de la Red de Estudios de Historia de la secularización y la laicidad (REDHISEL) e Investigador Asociado del Centro de Estudios de Historia Política (CEHP) de la UNSAM. Ha publicado Los intelectuales católicos y el fin de la cristiandad (1955-1966) (2006); Cristianos antifascistas. Conflictos en la cultura católica argentina (1936-1959) (2013) y Los humanistas universitarios. Historia y memoria (2018). Ha coordinado numerosas obras colectivas, entre las que se destacan Pasiones anticlericales. Un recorrido iberoamericano (2014) y Fronteras disputadas: religión, secularización y anticlericalismo en la Argentina (siglos XIX y XX) (2016) ambas junto a Roberto Di Stefano, y La reforma universitaria cuestionada (2018), junto a Diego Mauro. 